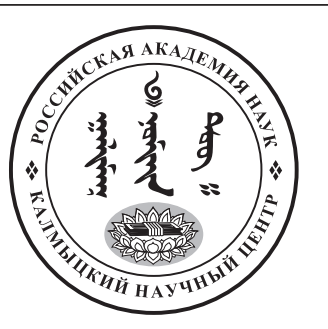

Published in the Russian Federation

Oriental Studies (Previous Name: Bulletin of the Kalmyk Institute

for Humanities of the Russian Academy of Sciences)

Has been issued as a journal since 2008

ISSN: 2619-0990; E-ISSN: 2619-1008

Vol. 14, Is. 5, pp. 929-936, 2021

Journal homepage: https://kigiran.elpub.ru

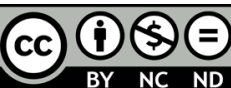

УДК / UDC 94(47).084.8

DOI: 10.22162/2619-0990-2021-57-5-929-936

\title{
Комсомольская организация Калмыкии и ее антирелигиозная деятельность (1921-1941 гг.)
}

\section{Баатр Андреевич Оконов ${ }^{1}$}

${ }^{1}$ Калмыцкий научный центр РАН (д. 8, ул. им. И. К. Илишкина, 358000 Элиста, Российская Федерация) научный сотрудник

D 0000-0001-8568-4330.E-mail: vostok80@mail.ru

(C) КалмНЦ РАН, 2021

(C) Оконов Б. А., 2021

Аннотация. Введение. Комсомол в советский период истории нашей страны являлся основной молодежной организацией, игравшей важную роль в формировании новой коммунистической идеологии. Цель статьи - анализ антирелигиозной деятельности компомольских организаций Калмыкии в 1921 - 1941 гг. Исследование проведено на основе вновь выявленных архивных материалов из Национального архива Республики Калмыкия, а также опубликованных источников. Результаты. Рассмотрены некоторые эпизоды антирелигиозной деятельности комсомольской организации Калмыкии в 1921-1941 гг. Архивные документы свидетельствуют, что, несмотря на активно проводимую антирелигиозную политику Советского государства, партийным и комсомольским органам не удалось наладить систему эффективной антирелигиозной пропаганды в Калмыкии. Особенности антирелигиозной деятельности комсомольской организации были связаны с многоконфессиональным составом населения Калмыкии. Ввиду отсутствия методических рекомендаций для борьбы с буддизмом комсомольцы использовали положительные практики антирелигиозной работы с христианством. Так, после успешно проведенного «комсомольского» рождества были введены «комсомольские» Цаган Сар и другие праздники. Также комсомольским областным органам рекомендовалось использовать в своей работе наступивший раскол в среде буддийского духовенства. В связи с проведенными репрессиями против духовенства всех конфессий во второй половине 1930-х гг. антирелигиозная деятельность комсомольской организации Калмыкии свелась к формальной работе.

Ключевые слова: Калмыцкая автономная область, советская власть, борьба с религией, номенклатура, Калмыцкий обком КСМ - ВЛКСМ

Благодарность. Исследование проведено в рамках государственной субсидии - проект «Комплексное исследование процессов общественно-политического и культурного развития народов Юга России» (номер госрегистрации: АААА-А19-119011490038-5).

Для цитирования: Оконов Б. А. Комсомольская организация Калмыкии и ее антирелигиозная деятельность (1921-1941 гг.) // Oriental Studies. 2021. T. 14 (5). С. 929-936. DOI: 10.22162/26190990-2021-57-5-929-936 


\title{
Komsomol Organization of Kalmykia and Its Antireligious Activity, 1921-1941
}

\author{
Baatr A. Okonov ${ }^{1}$
}

${ }^{1}$ Kalmyk Scientific Center of the RAS (8, Ilishkin St., 358000 Elista, Russian Federation)

Research Associate

iD 0000-0001-8568-4330. E-mail: vostok80@mail.ru

(C) KalmSC RAS, 2021

(C) Okonov B. A., 2021

\begin{abstract}
The article aims to examine episodes of anti-religious activity of the Komsomol organization of Kalmykia in 1921-1941. The research is based on archival and published materials. The analysis of archival documents shows that despite the anti-religious policy actively pursued by Soviet authorities, the local party and Komsomol organizations failed to establish a system of effective anti-religious propaganda in Kalmykia. Notably, in their anti-religious activity, the Komsomol members had to deal with the multi-confessional population in Kalmykia. Granted the lack of guidelines for organizing the campaign against Buddhism, they often had to rely on practices used in the anti-religious work against Christianity: e.g., to follow the successful example of 'Komsomol' Christmas, the Tsagan Sar and other Kalmyk holidays were also introduced as 'Komsomol' events. Also, it was recommended that in their anti-religious work, the Komsomol activists were to take advantage of the split of the Buddhist clergy. After repressions against the clergy of all confessions that took place in the late 1930s, the anti-religious activity of the Komsomol organization in Kalmykia was reduced to formal work.

Keywords: Kalmyk autonomous region, Soviet power, anti-religious activities, nomenklatura, Kalmyk regional committee of the KSM - Komsomol

Acknowledgements. The reported study was funded by government subsidy, project no. AAAA-A19-119011490038-5 'Sociopolitical and Cultural Development of South Russia's Peoples: Comprehensive Studies of Respective Processes'.

For citation: Okonov B. A. Komsomol Organization of Kalmykia and Its Antireligious Activity, 1921-1941. Oriental Studies. 2021. Vol. 14 (5): 929-936. (In Russ.). DOI: 10.22162/2619-09902021-57-5-929-936
\end{abstract}

\section{Введение}

В советский период истории Коммунистический союз молодежи (комсомол) занимал важное место в жизни нашей страны. С середины 1920-х и до начала 1990-х гг. комсомол являлся фактически основной молодежной организацией в СССР. При его посредстве советская власть проводила молодежную политику, осуществляла идеологическое воспитание молодежи, реализовала политические, социальные и экономические проекты.

Формирование новой коммунистической идеологии, отвергавшей религию, побудило представителей комсомола активнее участвовать в религиозной политике государства. В этих условиях становится актуальным осмысление истории формирования новой государственной религиозной политики и участие в ней молодежи.
К началу ХХ в. на территории Калмыкии проживали представители трех мировых религий - христианства, буддизма и ислама. В западной части Калмыцкой степи проживали переселенцы - русские и украинцы, исповедовавшие христианство. В восточной части, близ г. Астрахани, проживала небольшая часть татар-мусульман. Абсолютное большинство калмыков придерживалось ламаизма - одного из религиозных течений буддизма.

Целью данной статьи является анализ антирелигиозной деятельности комсомольской организации Калмыкии в 1921-1941 гг.

\section{Обзор литературы}

В последние десятилетия вышло значительное количество работ по истории участия комсомольских организаций в борьбе с религией. 
Начало систематическому изучению истории комсомола Калмыкии было положено выпуском сборника «Первые десять лет Калмыцкой областной комсомольской организации (1921-1931 гг.)», в котором, помимо очерков А. И. Наберухина и А. В. Мирошниченко, приводились воспоминания первых комсомольцев об участии в культурной революции [Первые десять лет 1963]. В работе Е. В. Сартиковой прослежен процесс формирования и развития школьного образования в Калмыкии. В ее монографии подробно рассмотрен период ликвидации неграмотности населения и участие комсомольцев в проводимом культштурме [Сартикова 2008]. С. С. Белоусов в своей монографии исследовал деятельность христианских организаций, действовавших на территории Калмыкии в 1917-1991 гг. В работе отражено участие комсомола в антирелигиозной агитации и работе ячеек «Союза воинствующих безбожников» [Белоусов 2016].

Огромный вклад в изучение истории Калмыкии советского периода внес профессор К. Н. Максимов. В своих трудах, которые для калмыцких историков уже стали классическими, он показал развитие республики в условиях социализма и осуществления советской национальной политики, эволюцию социально-политической системы региона, историю сталинских репрессий и др. В этих работах также отражено участие молодого поколения и комсомольской организации в общественно-политической жизни республики [Максимов 2004; Максимов 2018]. В 2006 г. была опубликована статья У. Б. Очирова, посвященная религиозной ситуации в Калмыкии накануне и в период Гражданской войны [Очиров 2006]. Статья посвящена проблеме взаимоотношений между конфессиями в 1917-1920 гг. Автор рассмотрел деятельность буддийского духовенства по расширению прав религиозных организаций после революции 1917 г. В статье приводится информация об отношениях между различными конфессиями и советской властью, которые в этот период носили непростой характер. В статье Ф. Л. Синицына «Советские безбожники и буддизм» автор осветил деятельность общественной организации «Союз воинствующих безбожников» в буддийских регионах СССР - Калмыкии и Бурятии [Синицын 2017].
Таким образом, ряд вопросов по деятельности комсомольских организаций в борьбе с религией еще требует дополнительного научного изучения.

\section{Материалы и методы}

В работе использованы материалы, хранящиеся в Национальном архиве Республики Калмыкия (НА РК). Среди них, в первую очередь, необходимо указать на документы Калмыцкого обкома комсомола (фонд П-22), а также улусных комитетов ВЛКСМ (фонды П-23, 24, 25, 26, 27, 28, 30, $31,32,33,34,35,36,37)$. Текущую характеристику состояния проводимой антирелигиозной комсомольской работы также дают статьи партийных и комсомольских работников, помещенных в газете «Ленинский путь». Необходимо отметить, что эти работы имели не столько аналитический, сколько просветительский и пропагандистский характер. Тем не менее, изучение этих статей позволяет не только вовлекать в научный оборот фактический материал, но и понимать особенности, дух того времени, официальную политику и взгляды руководства на те или иные события.

В работе использованы как общенаучные, так и специальные исторические методы исследования.

Начало работы комсомольской организации в Калмыцкой АССР

С установлением новой власти одной из первоочередных задач Коммунистической партии стало создание нового советского человека, свободного от религии. На VIII съезде РКП(б) в 1919 г. было принято решение, что партия должна разорвать связь между правящими классами и религиозными предрассудками, развернуть широкую образовательную и антирелигиозную пропаганду [КПСС в резолюциях 1954: 452]. Поэтому с момента организации Российский коммунистический союз молодежи (РКСМ) особое внимание в работе уделял коммунистическому воспитанию и антирелигиозной пропаганде в своих рядах.

Образованная в 1921 г. комсомольская областная организация Калмыкии первоначально была малочисленной. С ростом количества членов в ее рядах областная организация начала активно участвовать в общесоюзных комсомольских кампаниях. Согласно распоряжению обкома РКСМ, в 
декабре 1923 г. в рамках борьбы с религиозными праздниками там, где были ячейки РКП(б) и РКСМ, необходимо было подготовить и провести комсомольское Рождество, в случае же нехватки сил для мероприятия, проводить только беседу по естественным вопросам [НА РК. Ф. П-25. Оп. 1. Д. 1. Л. 42].

Для проведения комсомольского Рождества необходимо было создать комиссию при укоме РКП(б). В ее состав должны были войти заведующий агитационно-просветительским отделом (Зав. АПО), представители политпросвета, обкома РКСМ, УИК, на которых возлагалась подготовка и проведение комсомольского Рождества.

После проведения комсомольского Рождества всем профколлективам и комсомольским ячейкам рекомендовалось использовать все возможности для антирелигиозной пропаганды по клубам, детдомам, школам, избам-читальням и т. д.

В райцентре Приволжского улуса пос. Калмыцкий Базар вечером 7 января 1923 г. было проведено комсомольское Рождество. «Праздник начался карнавалом. Впереди шел звездоносец, за звездоносцем шла разряженная лошадь, к хвосту которой была привязана соломенная баба, олицетворяющая умирающую религию, затем шли наряженные участники, далее музыканты. Все шествие освещалось факелами. Присутствовали все члены РКСМ, молодежь и жители поселка. Во время шествия устроили три летучих митинга, на которых комсомольцы разъясняли происхождение религии, разоблачали религиозные догмы. Шествие завершилось митингом и спектаклем „Боевое крещение“. Также „комсомольское“" рождество было проведено и в Малодербетовском улусе в виде митинга на тему „Антирелигиозная пропаганда” и постановке спектакля. В остальных улуcax мероприятия не были проведены ввиду отсутствия средств, литературы и т. д.». [Сборник документов 1978: 41].

Пленум Калмыцкого обкома РКП(б), обсудивший в сентябре 1924 г. состояние антирелигиозной пропаганды, отметил слабость атеистической работы в области и поручил обкому комсомола разработать рекомендации по проведению национальных праздников и приступить к переизданию на родном языке общей антирелигиозной литературы. В свою очередь, на пленуме Калмыцкого обкома Российского Ленинского коммунистического союза молодежи (РЛКСМ) была принята резолюция, в которой был учтен поликонфессиональный характер и решено проводить в будущем не только комсомольское Рождество, но и комсомольский Цаган сар, Зул и другие религиозные праздники. Было решено по всей области при комсомольских ячейках организовать «коллективы антирелигиозной направленности и бытовой пропаганды», задача которых - изучение основ и обрядности буддизма и калмыцкого быта [Сборник документов 1978: 55].

Рекомендации в тезисах по улучшению антирелигиозной пропаганды среди молодежи обком комсомола направил во все улускомы для разработки на их основе своих мероприятий. В них были определены основные направления, по которым необходимо вести атеистическую пропаганду. Для ее улучшения предлагалось позаботиться о кадрах, организовать ячейки «безбожников», знать быт гелюнгов, внимательно знакомиться с настроениями буддийского духовенства. Особое внимание в тезисах обращалось на усиление антирелигиозной пропаганды среди женщин и детей. Вся работа должна была вестись в строгом согласовании с партийными ячейками.

Несмотря на проделанную работу, обком ВЛКСМ признавал, что антирелигиозная работа в области довольно слабая. «Слабость работы требует от нас серьезно подходить к данному вопросу, ведя работу в плоскости освобождения трудящихся масс от религии. Работу нужно вести в основном в указанных ниже направлениях:

1. Не останавливаясь перед отсутствием какой-либо литературы по проведению антирелигиозной работы, освещающей сущность ламаизма и пр., необходимо проводить агитацию на основе естественных наук, объяснения простых природных явлений, как-то: дождь, снег и пр., что явится громадным сдвигом в деле рассеивания религиозных чувств у населения.

2. Комсомольцы, отправленные заниматься антирелигиозной деятельностью на местах, часто бывают не подготовлены, поэтому дают неправильные разъяснения населению по вопросу религии. Отмечены случаи, когда комсомольцы, отвечая на вопрос граждан „есть ли бог“, ограничива- 
ются фразой: „нет бога потому, что его не видно“. Такие ответы подрывают авторитет организации и не приносят никакой пользы. Для правильности и плодотворности антирелигиозной работы надо иметь кадры подготовленных товарищей.

3. Подготовка кадров пропагандистов требует от нас организовать ячейку безбожников при наличии на то возможности. Работа в ячейках безбожников должна вестись в плоскости подготовки антирелигиозников, ознакомления их с естественной наукой и по возможности ламаизмом по программе, разрабатываемой, которая в скором времени будет выслана» [НА РК. Ф. П-22. Оп. 1. Д. 1. Л. 372].

Кроме того, обком комсомола признавал, что при ведении антирелигиозной пропаганды среди населения зачастую комсомольцы проявляли грубость, резкое и даже вульгарное отношение к религии и духовенству (откровенно ругали представителей духовенства, издевались над иконами и изображениями святых), такое поведение возмущало население, что, в свою очередь, подрывало авторитет организации. В дальнейшей антирелигиозной пропаганде такие отрицательные моменты рекомендовалось сглаживать, вырабатывая более выдержанный подход.

Большое значение руководящие органы придавали изучению повседневного быта гелюнгов и лам, в котором ими могли проявляться отрицательные моменты, противоречащие их учению (ламаизму), и т. п. В случае обнаружения таковых рекомендовалось разоблачать их среди населения, чтобы подорвать авторитет гелюнгов и лам в глазах населения.

Кроме того, в рамках борьбы с религией обком комсомола обращал внимание на то, что среди буддийского духовенства на тот момент имелось два течения, выявившиеся на съезде буддийского духовенства: консервативное и обновленческое. Обком ВЛКСМ признавал, что, по существу, оба течения вредные и рекомендовал поставить антирелигиозную пропаганду так, чтобы между представителями консервативного и обновленческого течений обострялись взаимоотношения, что должно было ослабить влияние духовенства. Для этого комсомольцам предлагалось ознакомиться с этими течениями [НА РК Ф. П-22. Оп. 1.
Д. 1. Л. 374]. Таким образом, как и в борьбе с православием, важным инструментом стало искусственное инспирирование раскола буддийского духовенства.

В подготовке и постановке антирелигиозной работы в деревне, аймаке и хотоне помощником комсомола признавался учитель. Комсомольским организациям на местах было рекомендовано связаться с учительством. В школах ставили вопрос об ознакомлении с элементарными понятиями безбожия, чтобы привить атеистический взгляд у учащихся, пионеров в школах. Наряду с этим комсомольцы проводили среди манджиков (буддийских монахов) разъяснительную работу по убеждению в ненужности религии и духовенства. Нахождение в хурулах манджиков, не достигших восемнадцатилетнего возраста, требовало от комсомольцев особой бдительности и необходимости отправлять сведения об этом в административные органы.

Вся антирелигиозная работа проводилась в строгой согласованности с партийными комитетами и ячейками на местах. Отдельно ставился вопрос об атеистической работе среди женщин. При такой работе с женщинами комсомольцы-агитаторы должны были объяснять вред религии с классовой точки зрения и приводить в пример связи православных священников с кулаками, буддийского духовенства с зайсангами и т.д.

В 1928 г. в Калмыкии были разработаны «Программа и методы работы религиозного кружка». При прохождении курса будущий специалист «пропагандист-массовик» должен был изучить следующие темы: «Объективная роль религии как орудие классового угнетения», «Субъективная сторона религии», «Как зародился буддизм и ламаизм, как облекался он обрядами», «Методы и содержание антирелигиозной пропаганды». Реализация принятой программы на местах была сопряжена с рядом проблем. Людей, «хорошо знакомых с буддизмом вообще и ламаизмом в особенности», было мало [Белоусов 2016: 56].

В 1928 г. руководством «Союза безбожников» было отмечено, что «в районах распространения ламаизма» антирелигиозная работа сотрудниками проводится на невысоком уровне, и решено «вплотную поставить вопрос о систематической борьбе» с буддизмом. Были поставлены следующие задачи: борьба с «шарлатанством лам и ти- 
бетской медициной», «разрешение вопроса о налоговом обложении ламства», а также «воспрещение бесконечных пожертвований» в пользу ламства, «принимающих массовый характер и являющихся прямо-таки разорительными для ... бедноты» [Синицын 2017: 242].

Во второй половине 1920-х гг. ЦК ВЛКСМ провел статистические обследования деятельности областных комсомольских организаций юга России. В 1929 г. на обследование работы Калмыцкой комсомольской организации был отправлен инструктор ЦК ВЛКСМ Кочурко ${ }^{1}$.

Несмотря на проводимую антирелигиозную работу, как заключил инструктор Кочурко, гелюнги имеют среди населения значительное влияние, в частности из-за родовых отношений. «В последнее время они всячески стараются усилить свое влияние путем устройства скачек, соревнований по народной борьбе с выдачей призов, пожертвования денег на строительство. Также духовенство активно выступают в качестве посредников или подрядчиков в строительстве, докторов тибетской медицины. Калмыцкая молодежь довольно охотно идет в манджики, активно осуществляет сбор денег на строительство хурулов. На религиозный праздник, где устраивались скачки, комсомольская ячейка Дальчинского аймака Харахусовского улуса уехала почти в полном составе, не проводя там никакой противоположной работы. В результате агитации гелюнга в Яндыках распался пионерский отряд.

$\mathrm{B}$ ячейке Ленинского аймака, где помещается областной хурул и областная буддийская философская школа, за три года ни одного вопроса антирелигиозного характера не поднималось. Комсомольцы и живущие при храме манджики живут дружно, ходят друг к другу в гости. Общество „Безбожник“ развито совершенно слабо, существующие ячейки почти не работают, нет комсомольского почина в развертывании вопросов естественно-научного характера» [НА РК Ф. П-22. Оп. 1. Д. 13 Л. 24].

Результаты обследования инструктора ЦК ВЛКСМ Кочурко были представлены в виде письменного доклада на IX Калмыцкой

\footnotetext{
1 Здесь и далее в соответствии с источником имена могут приводиться без отчества или инициалов.
}

областной конференции ВЛКСМ, которая состоялась 25-26 августа 1928 г. в Элисте. Этот доклад вызвал оживленную дискуссию на съезде, по итогам которого было решено указанные недостатки ликвидировать.

Комсомольская организация Калмыцкой АССР в 1930-е гг. и накануне Великой Отечественной войны

В рамках культштурма была продолжена борьба с религией. В связи с началом массовой коллективизации среди задач - поставить антибуддийскую пропаганду на «классовую точку зрения», в том числе вскрывать классовое «происхождение буддизма». В июне 1931 г. борьба с буддизмом обсуждалась на III пленуме Центрального совета Союза воинствующих безбожников (далее - СВБ) в рамках доклада М. С. Кобецкого «Итоги и перспективы антирелигиозной работы среди национальностей СССР». В 1932 г. СВБ выпустил свои первые антибуддийские брошюры на русском и бурятском языках «Происхождение буддизма» (2 600 экз.) и «Ламаизм и война» (2000 экз.) [Синицын 2017: 243].

В этот период продолжились жестокие репрессии против духовенства со стороны государства в национальных республиках. Всем областным парторганизациям страны был разослан секретный циркуляр ЦК ВКП(б) «О мерах по усилению антирелигиозной работы». В 1930 г. в Калмыкии к тюремным заключениям были приговорены 23 священнослужителя, в том числе 1 православный, 2 протестанта (лютеранин и пятидесятник) и 9 активистов. Летом 1931 г. за контрреволюционные выступления были арестованы более 10 багши, 24 гелюнга во главе с шаджин-ламой калмыцкого народа Шарапом Тепкиным. Всего, по данным Объединенного государственного политического управления (ОГПУ) по Калмыкии, были арестованы 53 священнослужителя, из них 45 осуждены к различным мерам наказания, в том числе 3 священника Русской православной церкви [Максимов 2004: 234235].

Кроме этого, комсомольскими органами проводились карательные мероприятия по отношению к комсомольцам, уличенным в связях с представителями духовенства. Так, в октябре 1937 г. был исключен из рядов комсомола член Лаганского улускома Тюрбя Басангов (по сообщению Нарана 
Дорджиева) за содействие своему отцу, который был председателем религиозного сообщества и агитировал за открытие в Лагани своего хурула [НА РК. Ф. П-27. Оп. 1. Д. 10. Л. 46об.]. Также в ноябре 1937 г. на заседании бюро Лаганского улускома была исключена Н. И. Тыньянова за сочувствие религиозным предрассудкам и венчание в церкви [НА РК. Ф. П-27. ОП. 1. Д. 10. Л. 57].

В числе старых форм быта, которые также подвергались гонениям, были гадания (в том числе святочные, «на суженого» и т. д.). Комсомолки, уличенные в таких поступках, подвергались порицанию или даже наказанию. Например, комсомолка Мария Бедрик за одно гадание была исключена из комсомола. Она подала апелляцию в конфликтную комиссию, и там «гадалку» простили, учитывая единичный факт «союзного преступления», восстановили в комсомоле, но вынесли ей предупреждение [НА РК. Ф. П-33. Оп. 1. Д. 3. Л. 63].

В начале 1937 г. на бюро Элистинского горкома ВКП(б) было решено усилить борьбу с религией во всех её проявлениях и обязать партийные организации создать ячейки «союза воинствующих безбожников» на местах. Кроме этого, партийные и комсомольские организации должны были оказать им помощь в проведении атеистической пропаганды и организации подписки на антирелигиозную литературу. При горкоме партии было организовано оргбюро СВБ и коллектив агитаторов из $10-15$ человек [Белоусов 2016: 63].

Партийные органы предпринимали определенные шаги в организационном и кадровом направлениях, чтобы придать эффективность антирелигиозной работе. В 1939 г. обкомом партии были проведены 15-дневные курсы подготовки антирелигиозных кадров, в которых участвовали 30 человек, предполагалось организовать постоянно действующий семинар антирелигиозников.

В 1939 г. была проведена первая конференция, на которой был создан республиканский СВБ. В 1940 г. были открыты его ячейки в улусах. Председателем республиканского Совета СВБ был назначен Г. Молоканов. С января 1940 г. по май 1941 г., как отмечал заведующий лекционным бюро республиканского совета СВБ К. Манджиев, среди населения республики было проведено 114 лекций по антирели- гиозным вопросам. На лекционную работу привлечены агрономы, врачи, учителя, партийные и комсомольские пропагандисты. Благодаря поставленной антирелигиозной пропаганде накануне Пасхи среди колхозников не было случаев ухода с работы [Манджиев 1941: 3].

В начале 1941 г. Г. Ш. Молоканов отмечал, что работа в улусах ведется слабо. На улусной конференции СБВ Троицкого улуса, проведенной в начале 1941 г., работа оргбюро первичных организаций признана неудовлетворительной. Там же на конференции был избран новый улусный совет в составе 5 человек [Кониев 1941: 2]. Также в 1940 г. в Черноземельском улусе не было проведено ни одной лекции, ни одного доклада на антирелигиозную тему. Улусный отдел образования и комитет комсомола ничего не сделали для развертывания антирелигиозный работы среди школьников и их родителей. Улусная комсомольская организация не выполняет программу ВЛКСМ, принятую Х съездом комсомола, где по вопросу об отношении к религии сказано, что комсомол должен терпеливо разъяснять молодежи вред суеверий и религиозных предрассудков [Молоканов 1941].

Весной 1941 г., накануне Великой Отечественной войны, чтобы усилить работу по антирелигиозной пропаганде, был приглашен лектор Центрального совета СВБ В. Гудъюргис. Им была опубликована большая статья «Нравственность и религия» в республиканской газете «Ленинский путь», проведен ряд лекций в г. Элисте для студентов политпросветшколы, работников кустарно-промысловых артелей и Калмгостеатра, учителей городских школ [Гудьюргис 1941].

\section{Заключение}

В 1920-е гг. деятельность партийных и комсомольских органов по проведению атеистической пропаганды среди населения можно признать малоэффективной. Лишь только репрессии религиозных организаций всех конфессий и ликвидация духовенства как социальной группы во второй половине 1930-х гг. позволили говорить о победе в этом направлении. Проводимая впоследствии в предвоенный период антирелигиозная пропаганда носила формальный характер и ограничивалась лекционными мероприятиями и публикациями в периодической прессе. 


\section{Источники}

НА РК - Национальный архив Республики Калмыкия.

\section{Литература}

Белоусов 2016 - Белоусов С. С. Государственная религиозная политика в Калмыкии в отношении христианского населения в годы Советской власти (октябрь 1917-1991 гг.). Элиста: Изд-во КалмНЦ РАН, 2016. 342 с.

Гудъюргис 1941 - Гудъюргис В. Нравственность и религия // Ленинский путь. 1941. 24 апреля. С. 2.

Кониев 1941 - Кониев М. Избран новый состав совета СБВ // Ленинский путь. 1941. 17 января. С. 2.

КПСС в резолюциях - КПСС в резолюциях и решениях съездов, конференций и пленумов ЦК. Изд. 9-е, доп. и испр. Т. 2. 1917-1922. М.: Политиздат, 1983. 606 с.

Максимов 2004 - Максимов К. Н. Трагедия народа: Репрессии в Калмыкии. 19181940-е годы. М.: Наука, 2004. 311 с.

Максимов 2018 - Максимов К. Н. Репрессии против буддийского духовенства — носителей национальной идеологии и духовности // Каспийский регион: политика, экономика, культура. 2018. № 3 (56). С. 23-29

Манджиев 1941 - Манджиев К. Кровное дело парторганизации // Ленинский путь. 1941. 30 мая. С. 3.

\section{References}

Belousov S. S. Christians of Kalmykia in the Soviet Era, October 1917 to 1991: State Religious Policy Reviewed. Elista: Kalmyk Scientific Center (RAS), 2016. 342 p. (In Russ.)

Koniev M. League of Militant Atheists: council reelected. Leninskiy put'. 1941, January 17. P. 2. (In Russ.)

Yegorov A. G., Bogolyubov K. M. (eds.) CPSU in Resolutions and Decrees of Congresses, Conferences and Plenary Sessions. 9 $^{\text {th }}$ ed., rev. and suppl. Vol. 2: 1917-1922. Moscow: Politizdat, 1983. 606 p. (In Russ.)

Maksimov K. N. Repression against Buddhist clergy - representatives of national ideology and spirituality. The Caspian Region: Politics, Economics, Culture. 2018. No. 3 (56). Pp. 23 29. (In Russ.)

Maksimov K. N. The National Tragedy: Repressions in Kalmykia, 1918-1940s. Moscow: Nauka, 2004. 311 p. (In Russ.)

Mandzhiev K. Cherished cause of our party organization. Leninskiy put'. 1941, May 30. P. 3. (In Russ.)
Sources

National Archive of the Republic of Kalmykia.

Молоканов 1941 - Молоканов Г. Оживить антирелигиозную работу // Ленинский путь. 1941. 4 января. С. 2.

Очиров 2006 - Очиров У. Б. Межконфессиональные отношения и религиозная ситуация в Калмыкии в 1917-1920 гг. // Вестник Российского университета дружбы народов. Серия «История России». 2006. № 1(5). С. 69-79.

Первые десять лет 1963 - Первые десять лет Калмыцкой областной комсомольской организации. (1921-1931 гг.). Документы, статьи, воспоминания / сост. А. В. Мирошниченко, А. К. Зундугинов, А. И. Наберухин. Элиста: Калмиздат, 1963. 184 с.

Сартикова 2008 - Сартикова E. В. Развитие школьного образования в Калмыкии в XX веке. Элиста: Джангар, 2008. 407 с.

Сборник документов 1978 - Сборник документов и материалов по истории Калмыцкой организации ВЛКСМ / сост. 3. Б. Очирова. Элиста: Калм. кн. изд-во, 1978. 307 с.

Синицын 2017 - Синицыьн Ф. Л. Советские безбожники и буддизм // Великая Российская революция в судьбах народов Юга России: мат-лы Всерос. научн. конф. (г. Элиста, 1315 августа 2017 г.). Элиста: КалмНЦ РАН, 2017. C. 240-250.

Molokanov G. Antireligious work be strengthened. Leninskiy put'. 1941, January 4. P. 2. (In Russ.)

Ochirov U. B. The relations between confessions and the religious situation in Kalmykia in 1917-1920. RUDN Journal of Russian History. 2006. No. 1(5). Pp. 69-79. (In Russ.)

Miroshnichenko A. V. et al. (comps.) Kalmyk Oblast Komsomol Organization: The First Ten Years, 1921-1931. Documents, articles, memoirs. Elista: Kalmizdat, 1963. 184 p. (In Russ.)

Sartikova E. V. Development of School Education in Kalmykia, $20^{\text {th }}$ Century. Elista: Dzhangar, 2008. 407 p. (In Russ.)

Ochirova Z. B. (comp.) History of Kalmykia's Komsomol: Collected Documents and Materials. Elista: Kalmykia Book Publ., 1978. 307 p. (In Russ.)

Sinitsyn F. L. Soviet atheists and Buddhism. In: The Great Russian Revolution in Destinies of South Russia's Peoples. Conference proceedings. Elista: Kalmyk Scientific Center (RAS), 2017. Pp. 240-250. (In Russ.)

Gudyurgis V. Morality and religion. Leninskiy put'. 1941, April 24. P. 2. (In Russ.) 